PSICOLOGIA, SAÚDE \& DOENÇAS, 2019, 20(3), 740-758

ISSN - 2182-8407

Sociedade Portuguesa de Psicologia da Saúde - SPPS - www.sp-ps.pt

DOI: http://dx.doi.org/10.15309/19psd200315

\title{
VALIDATION OF THE PARENTAL FEEDING STYLE QUESTIONNAIRE IN A PORTUGUESE SAMPLE
}

\author{
Filipa Pimenta ${ }^{2}$, Inês Queiroz Garcia ${ }^{2}$, Sofia Cristina $^{1}$, Diana Galvão ${ }^{1}$, João Marôco ${ }^{2}, \&$ Isabel Leal ${ }^{2}$ \\ ${ }^{1}$ ISPA - Instituto Universitário, Lisboa, Portugal, sofiafrancopereira@gmail.com,dmngalvao@gmail.com \\ ${ }^{2}$ William James Center for Research, ISPA - Instituto Universitário, Lisboa, Portugal, filipa_pimenta@ispa.pt, \\ igarcia@ispa.pt, joao.maroco@ispa.pt, ileal@ispa.pt
}

\begin{abstract}
Portugal is among the European countries with higher rates of overweight children, and parental feeding practices may affect children weight and eating patterns. A community sample of 252 Portuguese parents was used to study the psychometric properties of the Portuguese version of the Parental Feeding Style Questionnaire. (i.e., structural, convergent and discriminant validity, external and criterion validity, as well as reliability and sensitivity). Regarding construct validity, the measurement model supported a five-factor structure (Emotional, Instrumental, Encouragement, Permissiveness, and Control) with an acceptable fit; Item 24 was excluded since it showed a very low factor weight and was not significantly associated with its subscale $(\lambda=0.274 ; p=0.065)$; also, this item's explained variance was below the recommended $\left(r^{2}=0.018\right)$. Discriminant validity was verified in eight of the ten paired factors. Only the emotional eating subscale had a good value of VME (convergent validity; VME = .62). External validity was confirmed, as was internal consistency, where four of the five subscales, with the exception of the emotional eating subscale, had good Cronbach's alphas $(.67<\alpha<.88)$. The Portuguese sample reported the predominant use of permissiveness and control practices, similar to that reported by previous studies. The Portuguese Parental Feeding Style Questionnaire appears valid and reliable for assessing Portuguese parents feeding styles and can be used in further studies. The existence of culturally adapted and validated instruments is fundamental for an accurate understanding of parental practices, in order to develop strategies to manage children's dietary intake and prevent health-related problems, subsequent to overweight. Keywords: feeding, parental practices, children, validation, Portuguese.
\end{abstract}

\section{VALIDAÇÃO DO PARENTAL FEEDING STYLE QUESTIONNAIRE NUMA AMOSTRA PORTUGUESA}

RESUMO: Portugal é um dos países europeus com elevada prevalência de excesso de peso infantil, com implicações na saúde e bem-estar das crianças. As práticas alimentares parentais, como controlo, promoção/encorajamento, alimentação emocional

William James Center for Research, ISPA - Instituto Universitário, Rua Jardim do Tabaco, 34, 1149041, Lisboa, Portugal. Tel.: (+351) 21881 1700; Email: filipa_pimenta@ispa.pt 
e instrumental têm demonstrado influência no peso e nos padrões alimentares das crianças. O objetivo deste estudo foi avaliar as propriedades psicométricas da versão portuguesa do Parental Feeding Style Questionnaire. Uma amostra comunitária de 252 pais portugueses foi utilizada para estudar o constructo do instrumento (i.e., validade estrutural, convergente e discriminante), validade externa e de critério, bem como confiabilidade e sensibilidade. Os resultados suportam uma estrutura de 5 fatores (Emocional, Instrumental, Encorajamento, Permissividade e Controlo); o item 24 foi excluído $\left(\lambda=0,274 ; p=0,065 ; r^{2}=0,018\right)$ e os itens do Controlo foram distribuídos em duas subescalas. A validade discriminante foi verificada em oito dos dez pares de fatores; apenas a subescala de alimentação emocional apresentou um bom valor de VME (validade convergente; VME=0,62). A validade externa foi confirmada, assim como a consistência interna, onde quatro das cinco subescalas, com exceção da subescala de alimentação emocional, apresentaram bons alfas de Cronbach $(0,67<\alpha<0,88)$. A amostra portuguesa reportou o uso predominante de práticas de permissividade e controlo, similarmente ao reportado pelos estudos anteriores. $\mathrm{O}$ Parental Feeding Style Questionnaire evidencia ser válido para avaliar os estilos alimentares de pais portugueses semelhantes aos desta amostra. A existência de instrumentos culturalmente adaptados e validados é indispensável para o desenvolvimento de estratégias para gerir a ingestão alimentar das crianças e a prevenção de problemas relacionados com a saúde.

Palavras-chave: alimentação, práticas parentais, crianças, validação, Português.

Recebido em 08 de Agosto de 2019/ Aceite em 31 de Agosto de 2019

The Childhood Obesity Surveillance Initiative (COSI) has identified Portugal as one of the five European countries with a higher prevalence of overweight and childhood obesity (Rito, Sousa, Mendes, \& Graça, 2017). Although throughout the four phases of the COSI there had been a decrease in the prevalence of obesity, Portugal remained among the countries with the highest estimates. In 2016, Portugal had a prevalence of overweight of $30.7 \%$, less $7.2 \%$ than in 2008 . Likewise, the prevalence of obesity showed a decrease from $15.3 \%$ in 2008 to $11.7 \%$ in 2016 (Rito et al., 2017). Additionally, Portugal is in second place regarding overweight's prevalence among 11 years old, when compared with other countries of the WHO European Region (World Health Organization, 2014).

Identifying the predictors of childhood obesity is crucial, not only because of their link with obesity risk in subsequent years (Faienza, Wang, Frühbeck, Garruti, \& Portincasa, 2016), but mostly due to its negative effects during childhood and adolescence, such as type 2 diabetes mellitus, hypertension, early puberty, menstrual irregularities and polycystic ovary syndrome, steatohepatitis, sleep apnea, asthma, benign intracranial hypertension, musculoskeletal disorders, and psychological problems (Gozal et al., 2017; Muc, Mota-Pinto, \& Padez, 2016); adults with obesity are also at risk of developing most of these conditions (Bassuk \& Manson, 2017).

Obesity-inducing behaviours include the consumption of sugar-rich and energy-dense snacks (Jebb, 2005), sugar-sweetened drinks (Vartanian, Schwartz, \& Brownell, 2007); also, health-risk behaviours such as skipping breakfast (Wijnhoven et al., 2015) and frequent takeaway meal consumption (Donin et al., 2017) appear to be associated with unhealthy dietary intake and long term consequences for obesity. On the contrary, fruit consumption (Lock, Pomerleau, Causer, Altmann, \& McKee, 2005) and daily breakfast consumption (Dubois, Girard, Potvin Kent, Farmer, \& Tatone-Tokuda, 2008) have been found to be associated with having a healthy body weight. 
Several biological maternal-related factors (e.g., genetic, endocrine) are already identified as being associated with obesity (Pan et al., 2019); however, contextual factors, such as family, seem also to be determinant in childhood obesity (Kaufman \& Karpati, 2007). The family has been identified as the early and most fundamental context in which eating behaviours are established, by selecting, modelling and giving directions on when, what and how much to eat (Arcan et al., 2007).

Parental feeding style has been associated with intergenerational transmission of obesity and children's eating behaviours (Ventura \& Birch, 2008; Wardle, Sanderson, Guthrie, Rapoport, \& Plomin, 2002), including not only the exposure to food (quantity, quality, frequency), but also the social context of the meals (e.g., eating while watching television) and reactions to children's eating behaviours (Daniels et al., 2009). More specifically, two areas of parenting have been considered: parental styles (how parents interact with their children) and parental practices (behavioral strategies that parents use to socialize their children) (Darling \& Steinberg, 1993; Ventura \& Birch, 2008).

Baumrind's theory of parenting styles (Baumrind, 1971, 1989) considered three types of parental control (authoritarian, authoritative, permissive) and was later extended by Maccoby and Martin (1983) by establishing four parenting styles according to a two-dimensional framework: 1) authoritarian - high demandingness and low responsiveness; 2) authoritative - high demandingness and high responsiveness; 3) permissive - low demandingness and high responsiveness; and 4) uninvolved - low demandingness and low responsiveness.

Parenting styles have been applied to the feeding subject, often considering an equivalent typology of four feeding styles. Parental feeding practices refer to specific actions used to enable or limit specific food consumption, being the most present in literature: pressure to eat - pressuring a child to consume more healthy foods or increase overall food consumption (Birch et al., 2001); and restriction - decreasing a child's intake of unhealthy foods (Faith, Scanlon, Birch, Francis, \& Sherry, 2004). Other feeding practices are referred, namely, instrumental and emotional feeding using food as a reward or to help children in regulating emotions (Rodenburg, Kremers, Oenema, \& van de Mheen, 2014; Wardle et al., 2002); parental food modelling - children learning by observation and vicarious reinforcement (Dickens \& Ogden, 2014; Ventura \& Birch, 2008); monitoring - keeping track of a child's eating (Birch et al., 2001); and prompting/encouragement to eat - which might derive from the parents' keenness to get the child to eat carefully prepared food or the belief that a heavier child is healthier (Wardle et al., 2002). Encouragement is also shown in a positive form, as encouraging specifically eating healthy foods (Cullen et al., 2001) and providing appropriate guidance (Grolnick \& Pomerantz, 2009).

Several authors associate parenting styles and parental feeding practices (Hubbs-Tait, Kennedy, Page, Topham, \& Harrist, 2008; Hughes, Power, Fisher, Mueller, \& Nicklas, 2005; Vereecken, Rovner, \& Maes, 2010) with children's both negative and positive health-related outcomes (such as body weight, eating patterns or self-control).

Controlling feeding styles, such as restriction and pressure to eat, have been related to several negative outcomes: increase in the preference for forbidden foods (Jansen, Mulkens, \& Jansen, 2007), higher consumption of unhealthy food (Vereecken, Legiest, De Bourdeaudhuij, \& Maes, 2009), decrease in children's ability to respond to their internal cues of hunger (Ventura \& Birch, 2008) and satiety (Carper, Fisher, \& Birch, 2000), eating in response to emotions such as boredom or sadness (Carper et al., 2000), loss of control over eating (Neumark-Sztainer, Wall, Haines, Story, $\&$ Eisenberg, 2007) and overweight (Hurley, Cross, \& Hughes, 2011). A lower child consumption of fruit (Gregory, Paxton, \& Brozovic, 2011) and vegetables (Fisher, Mitchell, Smiciklas-Wright, \& Birch, 2002) has also been observed as associated with pressure to eat; it is suggested that this is a consequence of the children's perception of being forced to consume certain foods (e.g., soup), developing a "cognitive aversion" for those foods by associating them with the negative feeding experience and consuming them less (Galloway, Fiorito, Francis, \& Birch, 2006). 
Feeding practices based on the use of food for reward had a positive association with energydense snack intake (Rodenburg et al., 2014). Benton (2004) suggested that instrumental feeding could reinforce the preference for the reward, frequently, a high-calorie food. Emotional feeding was positively associated with weight status and obesogenic eating behaviours, as it encourages children to eat in the absence of hunger (Sleddens, Kremers, De Vries, \& Thijs, 2010). Vereecken et al. (2009) showed that parental encouragement through negotiation had a positive impact on dietary habits among sixth graders, and maternal encouragement promoted the intake of varied and healthy foods, which was found to be related to lower child body mass index (BMI) (Musher-Eizenman, de Lauzon-Guillain, Holub, Leporc, \& Charles, 2009).

Given the increase in childhood overweight and obesity, and considering the impact that parental feeding behaviours might have on children's former development, several measures have been developed to assess parental styles and practices. The development of culturally appropriate instruments to identify factors that may be related to childhood overweight is essential to understand the mechanisms involved in such process and establish adequate prevention and intervention measures for children's eating problems and overweight. Thus, the purpose of this study is to validate a Portuguese version of the Parental Feeding Style Questionnaire.

\section{METHODS}

\section{Participants}

The present community sample was collected mainly through schools in Lisbon (Portugal). Inclusion criteria were having at least one child aged between 2 and 18 years. In total, 252 parents filled in all measuring instruments. Participants' characteristics are shown in Table 1. 
Table 1. Characterisation of the Participants.

\begin{tabular}{|c|c|c|}
\hline & Mean $(S D)$ & $n(\%)$ \\
\hline Age & $37.7(6.31)$ & - \\
\hline \multicolumn{3}{|l|}{ Sex } \\
\hline Female & - & $224(88.9)$ \\
\hline Male & - & $28(11.1)$ \\
\hline \multicolumn{3}{|l|}{ Parity } \\
\hline 1 or 2 children & - & $231(91.7)$ \\
\hline More than 2 children & - & $21(8.3)$ \\
\hline \multicolumn{3}{|l|}{ Relationship status } \\
\hline With an affective-sexual relationship & - & $229(90.9)$ \\
\hline Without an affective-sexual relationship & - & $23(9.1)$ \\
\hline \multicolumn{3}{|l|}{ Education level } \\
\hline Primary school & - & $4(1.6)$ \\
\hline Middle school & - & $39(15.5)$ \\
\hline High school & - & $50(19.8)$ \\
\hline College degree & - & $159(63.1)$ \\
\hline \multicolumn{3}{|l|}{ Professional status } \\
\hline Active & - & $224(88.9)$ \\
\hline Inactive & - & $25(9.9)$ \\
\hline Other & - & $3(1.2)$ \\
\hline \multicolumn{3}{|l|}{ Parent's BMI } \\
\hline Below normal & - & $4(1.6)$ \\
\hline Normal weight & - & $139(55.2)$ \\
\hline Overweight & - & $71(28.2)$ \\
\hline Obesity & - & $38(15.1)$ \\
\hline \multicolumn{3}{|l|}{ Recent disease } \\
\hline Yes & - & $29(11.5)$ \\
\hline No & - & $223(88.5)$ \\
\hline \multicolumn{3}{|l|}{ Recent psychological problem } \\
\hline Yes & - & $17(6.7)$ \\
\hline No & - & $235(93.3)$ \\
\hline
\end{tabular}

BMI, body mass index; $S D$, standard deviation.

\section{Material}

Sociodemographic Questionnaire. A questionnaire was applied to collect self-reported sociodemographic (e.g., sex, age, schooling), health status (e.g., the presence of a disease) and weight status.

Parental Feeding Style Questionnaire (PFSQ). PFSQ was originally developed in the United Kingdom by Wardle et al. (2002). The questionnaire consists of 27 items organized into four scales, including emotional feeding (five items), instrumental feeding (four items), prompting/encouragement to eat (eight items), and control over eating (ten items). Five items in control over eating are reversed. It is answered on a 5-point rating scale ranging from 1 (never) to 5 www.sp-ps.pt 
(always), meaning that a higher score corresponds to a higher tendency for the adoption of a specific style. Evidence supporting the reliability and validity of this instrument has been previously reported in Turkey, China, and Russia (Özçetin, Yilmaz, Erkorkmaz, \& Esmeray, 2010; Surkov, Pavlovskaya, Caroli, \& Kaganov, 2012; Tam, Keung, Lee, Lo, \& Cheung, 2014).

Generalized Expectations of Control Scale (GECS). GECS was developed by Palenzuela, Gerardo, Barros, and Almeida (1997) and adapted to the Portuguese language by Silva (2010). This 20-item four-factor instrument [self-efficacy/expectancy for success (eight items), luck (four items), contingency (four items), and non-contingency (four items)] is answered using a Likert-type scale ranging from 1 (totally disagree) to 9 (totally agree). Previous findings support the validity and reliability of the GECS (Silva, 2010).

Dutch Eating Behavior Questionnaire (DEBQ). DEBQ was originally developed by Van Strien, Frijters, Bergers, and Defares (1986) and adapted to Portuguese by Viana and Sinde (2003). It comprises 33 items, answered on a 5-point rating scale ranging from 1 (never) to 5 (very frequently), and organized in three subscales: restrain (10 items), emotional eating (10 items), and external eating (13 items). Evidence supporting the reliability and validity of this instrument has been previously reported (Viana \& Sinde, 2003).

\section{Translation of the Parental Feeding Style Questionnaire (PFSQ)}

In order to achieve semantic and conceptual similarity between the Portuguese and the original English version of the PFSQ, a translation and back translation were done independently by two bilingual health professionals. During the process, replication of the original sentences' structure and meaning, and sensitivity to cultural adjustment were also considered in the process (Behlin \& Law, 2000). At last, there was no need to make any language adjustments, so the items of the Portuguese version of the PFSQ remained the same as the ones in the English version (cf. Appendix).

\section{Procedure}

Several schools in the area of Lisbon were contacted, and permission to distribute the questionnaire to parents, teachers and school staff was acquired. Permission to use the Portuguese version of the DEBQ was obtained (license agreement ref: 14b1422jr). After confirming the inclusion criteria, written informed consent was obtained, and the questionnaires were distributed to the participants. This research followed the standards of the Portuguese Psychologist Association (2011) and the American Psychological Association (2003) regarding the ethical treatment of participants, and ethical validation of the project was given by the Health Group Coordination of the William James Center for Research.

\section{Data analysis}

Missing values were imputed for variables where its frequency was lower than $10 \%$ of the sample. This was done using the mean interpolation method.

The construct validity of the PFSQ was asserted by confirmatory factor analysis, convergent and discriminant validity. The goodness of fit of the measurement model was given by chi-square 
statistics $\left(\chi^{2} / d f\right)$, comparative fit index (CFI), goodness of fit index (GFI), root mean square error of approximation (RMSEA), and standardized root mean square residual (SRMR). Reference values indicative of good model fit were those currently applied in structural equation modeling (Byrne, 2016; Hu \& Bentler, 1995; Schermelleh-Engel, Moosbrugger, \& Müller, 2003).

Convergent validity was analysed through the average variance extracted (AVE), considering adequate if AVE was higher than .5 (Hair, Black, Babin, \& Anderson, 2009). The discriminant validity was explored comparing the inter-factors' squared correlation with the AVE of each factor. To demonstrate the factors' discriminant validity, the squared correlation between factors should be smaller than the individual factors' AVE (Marôco, 2014).

In addition, to demonstrate the stability of the original structure of the instrument and assert external validity of the measurement model, initial confirmatory factor analysis was carried out in $50 \%$ of the sample, randomly selected, and the factor weights and correlations stability were confirmed in the remaining 50\% of the sample through a multi-group analysis of invariance CFA (Marôco, 2014).

Criterion validity was explored through concurrent-oriented validity of scales, using Pearson's correlation with similar constructs (Cohen, 1988).

Cronbach's alpha and composite reliability (CR) were also computed, values higher .6 and .7 were considered acceptable and good, respectively (P. Kline, 2000).

Sensitivity was explored through the analysis of minimum and maximum values, skewness, and kurtosis. Values are expected to range through the overall Likert-type scales (from the minimum to the maximum scores) and skewness and kurtosis are expected to have absolute values below three and seven respectively (R. B. Kline, 2015; Marôco, 2014).

Finally, to explore whether there are significant differences between parents with normal weight, overweight, and obesity (excluding the parents with a weight below normal, given that this group was very small: $n=4$ ), regarding the five parental feeding styles, a one-way analysis of variance (ANOVA) was applied. Levene's test was used to assess the homogeneity of variances. In the case of heterogeneity of variances, Games-Howell post-hoc test was applied for multiple comparisons.

All statistical analysis was performed using software IBM SPSS Statistics and SPSS AMOS (v. 25, IBM Corp., Armonk, NY).

\section{RESULTS}

\section{Construct validity}

Confirmatory factor analysis. A baseline model was tested with the PFSQ-27 individual items. Based on the analysis of the statistical significance of parameter and of the standardized regression weight, item 24 ("I insist my child eats meals at the table") showed a very low standardized factor weight and was not significantly associated with its subscale $(\lambda=.274 ; p=.07)$; also, the value of the squared multiple correlations was below the recommended $.250\left(r^{2}=.018\right)$. In addition, this item displayed an absolute kurtosis above the recommended values (i.e., $7 ;|k u|=8.50$ ). Therefore, item 24 was excluded.

The modification indices pointed to a correlation of the errors between the items 17-20, 5-26, 517, 17-26, 4-27, and 10-12. After inserting the correlations, the fitness of the four-factor model proved to be acceptable $\left(\chi^{2} / d f=1.845 ; \mathrm{CFI}=.883 ; \mathrm{GFI}=.862 ; \mathrm{RMSEA}=.058 ; p<.001 ;\right.$ C.I. $90 \%=] .050 ; .066[$ SRMR=.087). Figure 1 presents the standardized factorial weights and individual items reliability. 
Filipa Pimenta, Inês Queiroz Garcia, Sofia Cristina, Diana Galvão, João Marôco, \& Isabel Leal

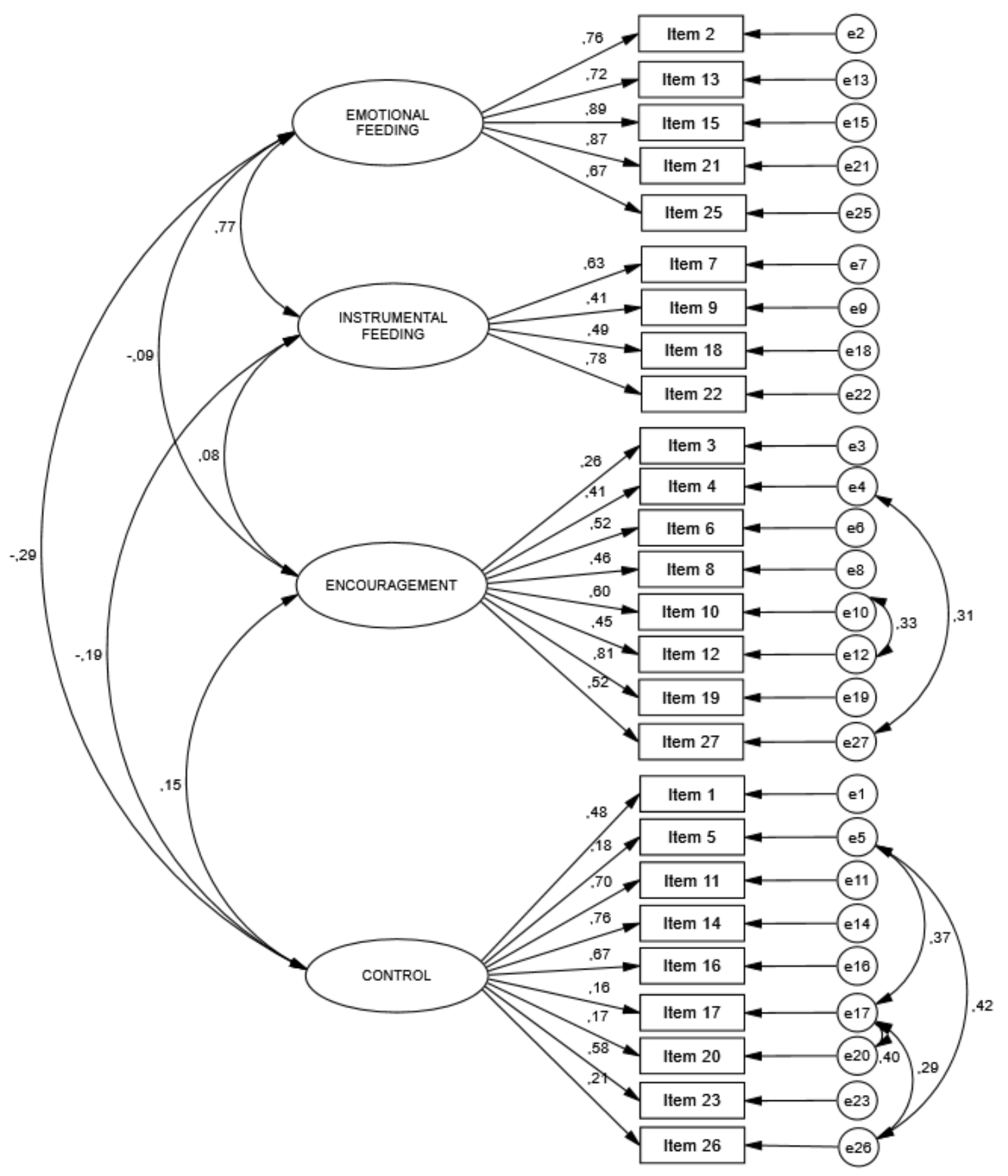

Figure 1. Baseline model for the confirmatory factor analysis.

The model without item 24 presents a good fit, and most factorial weights are adequate. However, subscale Control points to four items (5, 17, 20 and 26) with very low factorial weights. A second model was tested, dividing the subscale Control into two distinct constructs. Indeed, a better model fit for the five-factor model was achieved $\left(\chi^{2} / d f=1.536\right.$; CFI $=.926$; GFI $=.884$; RMSEA=.046; $p<.001$; C.I. $90 \%=] .037 ; .055[$; SRMR=.061). The standardized factorial weights and individual items' reliability for the PFSQ are presented in Figure 2. 


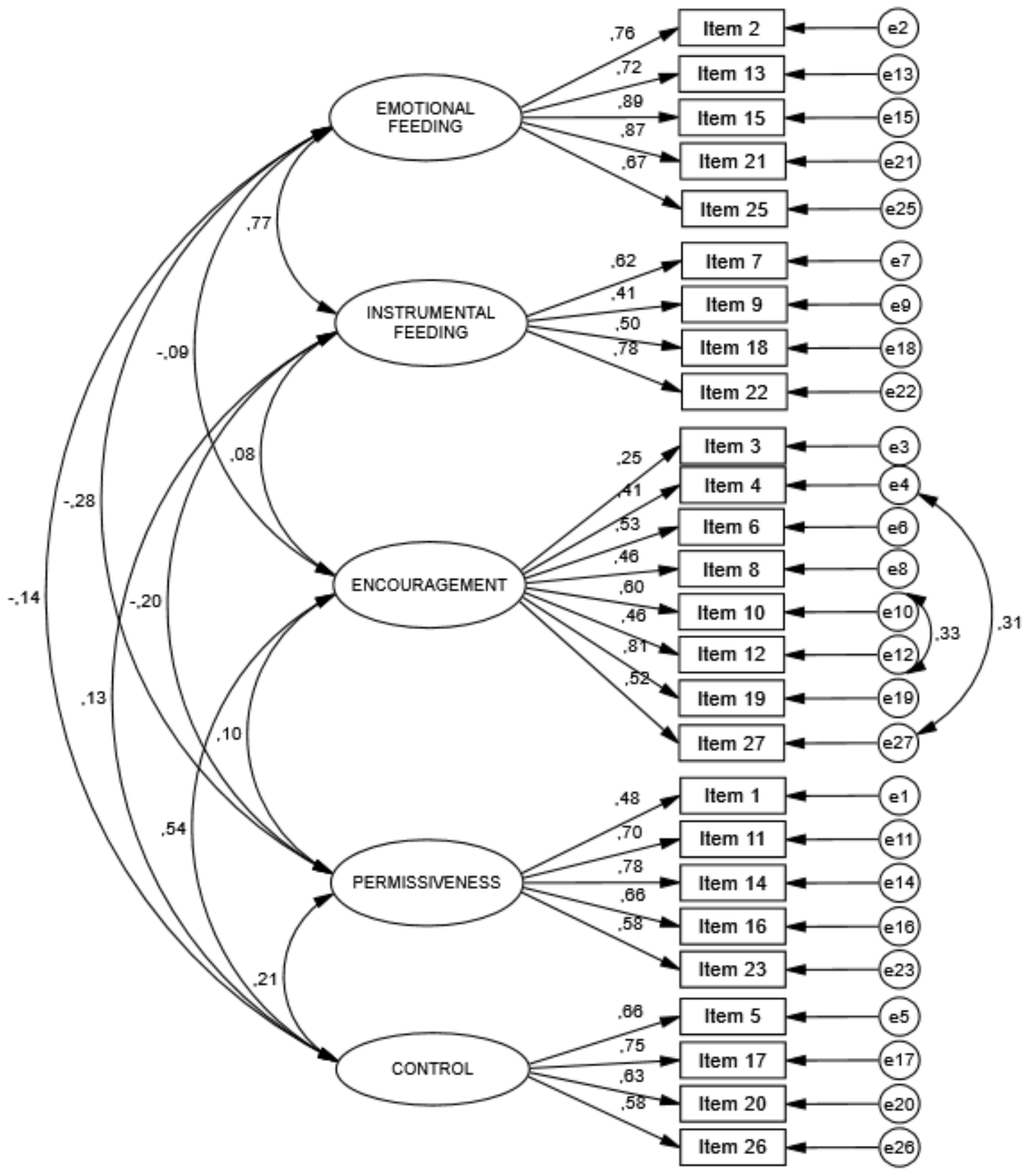

Figure 2. Final model for the confirmatory factor analysis.

Convergent validity. Convergent validity for PFSQ was assessed through AVE. Only emotional feeding subscale presented a good AVE score. The AVE for encouragement, instrumental feeding, permissiveness, control, and emotional feeding were $.28, .35, .42, .43$, and .62, respectively.

Discriminant validity. Discriminant validity for PFSQ subscales is listed in Table 2. Of the ten paired-factors possible comparisons, only eight presented discriminant validity. 
Table 2. PFSQ Factors' Discriminant Validity $(\mathrm{N}=252)$.

\begin{tabular}{lcc}
\hline Association between different factors & Squared correlations & Discriminant validity \\
\hline Emotional feeding $\leftrightarrow$ Instrumental feeding & .589 & No \\
Emotional feeding $\leftrightarrow$ Encouragement & .009 & Yes \\
Emotional feeding $\leftrightarrow$ Permissiveness & .078 & Yes \\
Emotional feeding $\leftrightarrow$ Control & .021 & Yes \\
Instrumental feeding $\leftrightarrow$ Encouragement & .005 & Yes \\
Instrumental feeding $\leftrightarrow$ Permissiveness & .04 & Yes \\
Instrumental feeding $\leftrightarrow$ Control & .018 & Yes \\
Permissiveness $\leftrightarrow$ Encouragement & .001 & Yes \\
Permissiveness $\leftrightarrow$ Control & .042 & Yes \\
Control $\leftrightarrow$ Encouragement & .294 & No \\
\hline
\end{tabular}

\section{External validity}

The model presents a good fit $\left(\chi^{2} / d f=1.386 ; \mathrm{CFI}=.900 ; \mathrm{GFI}=.810 ; \mathrm{RMSEA}=.039 ; p=.99\right.$; C.I. $90 \%=] .032 ; .046[$ ) in both groups (test group versus validation sample, obtained by random splitting the total sample in two).

The constrained measurement model with factorial weights $(\lambda)$, intercepts $(i)$, and fixed variances/covariances $(c o v)$ in both groups did not present a significantly worse adjustment than the unconstrained measurement model $\left(\Delta \chi^{2} \lambda(21)=30.475, \quad p=.08 ; \quad \Delta \chi_{i}^{2}(26)=30.203, \quad p=.26\right.$; $\left.\Delta \chi_{\operatorname{cov}}^{2}(15)=24.281, p=.06\right)$. Therefore, the external validity of the measurement model was confirmed through a strong invariance of the model across groups. Hence, there weren't significant differences in the factorial measurement weights between the two groups and the stability of the parental feeding's construct, as measured by the PFSQ, was confirmed.

\section{Criterion validity}

Criterion validity was explored through concurrent-oriented validity of scales, using Pearson's correlation with similar/divergent constructs. With that purpose, the Portuguese adaptation of the GECS (entailing four scales: luck, self-efficacy/expectancy for success, contingency, noncontingency) and the DEBQ (measuring emotional, external eating and restrain) were used. Emotional and instrumental feeding showed positive weakly significant correlations with GECS luck and non-contingency, and DEBQ external eating $(.18<r<.27)$; and negative weakly significant correlations with GECS self-efficacy/expectancy for success and contingency $(-.15<r<-.27)$. Only emotional feeding revealed a positive weakly significative correlation with DEBQ emotional eating $(r=.20)$. Encouragement showed positive weakly significant correlations $(.21<r<.25)$ with GECS self-efficacy/expectancy for success and contingency; and, negative weakly correlation with GECS non-contingency $(r=-.13)$. Permissiveness showed negative weakly significant correlations $(.19<r<.25)$ with GECS luck and non-contingency, and with DEBQ emotional and external eating. Control revealed a positive weakly significant correlation with GECS contingency $(r=.15)$, and negative weakly associated with GECS non-contingency $(r=-.14)$.

\section{Reliability: internal consistency and composite reliability}

The internal consistency and CR for the PFSQ subscales were also explored. As shown in Table 3 , all the subscales evidenced acceptable to good reliability $(.67<\alpha<.88$, and $.67<C R<.89)$. 
Table 3. Descriptive Statistics and Reliability Analysis for PFSQ (N=252).

\begin{tabular}{lccccc}
\hline Subscales & $\begin{array}{c}\text { Nr. } \\
\text { Items }\end{array}$ & $\begin{array}{c}\text { Mean score } \\
\text { (SD) }\end{array}$ & $\begin{array}{c}\text { Range of } \\
\text { scores }\end{array}$ & $\begin{array}{c}\text { Cronbach's } \\
\text { alpha }\end{array}$ & $\begin{array}{c}\text { Composite } \\
\text { reliability }\end{array}$ \\
\hline Emotional feeding & 5 & $1.49(.61)$ & 1.00 to 3.60 & .88 & .89 \\
Instrumental feeding & 4 & $1.60(.60)$ & 1.00 to 4.25 & .67 & .67 \\
Encouragement & 8 & $3.78(.62)$ & 1.25 to 5.00 & .74 & .74 \\
Permissiveness & 5 & $3.96(.77)$ & 1.00 to 5.00 & .77 & .78 \\
Control & 4 & $3.88(.83)$ & 1.00 to 5.00 & .75 & .75 \\
\hline
\end{tabular}

$S D$, standard deviation.

\section{Distributional properties}

To address eventual problems with the items' responses distributions, the range of the five-point Likert-type scale was explored, as well as skewness and kurtosis values of the PFSQ individual items. Except for item 24 (which showed an unacceptable kurtosis), all items presented acceptable skewness $(-2.85<S k<2.37)$ and kurtosis $(-.91<K u<6.71)$ values; with answers ranging from one to five. These results attest no distributional properties problems that would recommend against further factor analysis with maximum likelihood estimation.

\section{Parent's BMI classes and parental feeding styles differences}

An ANOVA was conducted to explore the impact of the parents' BMI classes on parental feeding styles as measured by the PFSQ. There were no differences between parents with normal weight, overweight, and obesity concerning, emotional feeding, instrumental feeding, encouragement, and control. Nonetheless, there was a statistically significant difference at the $p<.001$ level in permissiveness subscale for the parents' BMI classes: $F(2,83)=12.31, p<.001$. Despite reaching statistical significance, the actual difference in mean scores between groups was medium. The effect size, calculated using eta squared, was .13. Post-hoc comparisons using the Games-Howell test indicated that parents with normal weight $(M=4.15, S D=.58)$ manifested a significantly higher permissiveness when compared with their counterparts with overweight $[M=3.83, S D=.75 ; d=.50$ (medium effect size) $]$ and obesity $[M=3.40, S D=1.06 ; d=1.07$ (large effect size)].

\section{DISCUSSION}

Parental feeding practices have been an issue of interest that has increased in recent years due to their potential to affect food consumption behaviors, child obesity (Birch et al., 2001), and food preferences (Northstone \& Emmett, 2008; Unusan, 2006). Enhancing scientific insight into these problems and the use of valid and reliable measures seems necessary given the high prevalence of disturbed eating, since early ages and continuing through adolescence (Matton, Goossens, Braet, \& Van Durme, 2013).

A systematic review carried out by Vaughn, Tabak, Bryant, and Ward (2013) identified 71 instruments assessing parental feeding practices, including the PFSQ, and concluded about the substantial variation in the items across different scales and constructs, making a comparison between instruments demanding, and suggesting the development and validation of instruments. 
The present study had the purpose of validating the PFSQ to Portuguese. In this sample, participants appeared to practice more frequently permissiveness, control, and encouragement, with less frequent instrumental and emotional feeding. This was similar to the original study (Wardle et al., 2002) whose mothers reported higher levels of control and prompting and lower levels of instrumental and emotional feeding.

These results have also been confirmed in a Chinese sample (Tam et al., 2014), where the most reported feeding practice was control over eating - two-factor structure, followed by prompting/encouragement, instrumental feeding, and emotional feeding. In the Turkish sample (Özçetin et al., 2010), the preferred feeding practices were encouragement and restrictive control considering a two-factor structure, followed by emotional, permissive control and instrumental. Despite the existence of Russian validation of the questionnaire (Surkov et al., 2012), it has not been possible to access it to compare validation results.

Similarly, from previous validation of the PFSQ (Özçetin et al., 2010; Tam et al., 2014), in this study, the control subscale was confirmed as a two-factor construct. However, item 24 was not associated with this construct and was removed, improving the fit of the acceptable measurement model. The low factor regression weight for Item 3 suggest the need to review the formulation of the item in the Portuguese version of the PFSQ.

Instrumental and emotional feeding practices share the concept of reward; probably due to their proximity, the two subscales showed no discriminant validity. External and criterion validity were confirmed. Concerning convergent validity, only emotional feeding presented a good AVE score, indicating that the questionnaire assesses five close constructs, however, not associated enough to compose a second order (broader) factor.

To correct the correlations between the items' errors (assessed through modification indices Lagrange Multipliers), six correlations were assumed to improve the model fit. Correlated errors between the items 17-20 ("I decide when it is time for my child to have a snack"; "I decide the times when my child eats his/her meals"), 5-26 ("I decide how many snacks my child should have"; "I decide what my child eats between meals"), 5-17 ("I decide how many snacks my child should have"; "I decide when it is time for my child to have a snack"), and 17-26 ("I decide when it is time for my child to have a snack"; "I decide what my child eats between meals"), from the control over eating subscale; and items 4-27 ("I praise my child if s/he eats what I give him/her; "I praise my child if s/he eats a new food") and 10-12 ("I encourage my child to taste each of the foods I serve at mealtimes"; "I encourage my child to try foods that s/he hasn't tasted before") from prompting and encouragement to eat subscale were inserted, improving the measurement model fit. These assume correlations represent that each pair shares an underlying communality. For example, the first pair refers to a restrictive control regarding snacks; the fourth pair involves prompting through praising.

In what refers to reliability, except for the instrumental feeding subscale $(\alpha=.67)$, all the other subscales presented a good Cronbach's alpha, ranging from .74 (encouragement) to .88 (emotional feeding), supporting the instrument's reliability. The original study obtained a Cronbach's alpha ranging from .67 (instrumental) to .83 (emotional), while in validation studies the following were obtained: Tam et al. (2014) - from .63 (control over eating and instrumental feeding) to .83 (prompting/encouragement); Özçetin et al. (2010) - from .54 (permissive control) to .74 (encouragement).

This study, as Wardle et al. (2002) found that normal-weight parents didn't differ from their counterparts with obesity in terms of control, encouragement, emotional and instrumental practices; however, they did regarding permissiveness, which might suggest the importance of overlooking the relation between low parental control and children's eating and weight-related outcomes.

Some limitations should be accounted concerning the present findings, particularly the fact that this research had a cross-sectional design, and uses a convenience sample, where $63.1 \%$ of the 
sample has a college degree, limiting the generalization of the results. The sample size used for the structural equation modelling corresponded to a rule of thumb of nearly ten participants per manifest variable found adequate for this type of statistical analysis (R. B. Kline, 2015).

Our study addresses the insufficiency of validated instruments in this domain, considering the Portuguese reality. Moreover, it is important to note that Portugal is among the European countries with a higher prevalence of overweight children, calling attention to the pertinence of reliable assessment and ground-based intervention with children and their parents.

In conclusion, the inconsistent findings in the literature and the limited number of longitudinal studies about feeding styles/practices and weight and health-related outcomes have highlighted the need for additional research in this area. Although multiple studies have found associations between parental feeding behaviors and children's weight (Birch \& Fisher, 2000; Golan \& Crow, 2004), the literature is not consensual and some authors (Ventura \& Birch, 2008) state that other mechanisms may be present in the relationship between parental feeding behaviors and children's weight, specifically children's eating behaviors and the family contexts of feeding behaviors. The PFSQ appears as a potentially valid and reliable measure to include in further research; however, results should be interpreted in light of study limitations.

\section{Implications for Research and Practice}

The objective of this study was to validate a Portuguese version of the Parental Feeding Style Questionnaire in Portuguese parents. This validated instrument enables the evaluation of a variable that can predict eating and weight disorders and has the potential to precociously detect dysfunctional parental practices. Also, the validation of this widely used instrument to a specific culture allows the comparison of results among different cultural contexts.

\section{FINANCIAL SUPPORT}

This work was supported by a research grant of FCT - Portuguese Foundation for Science and Technology (grant SFRH/BPD/77799/2011). William James Center for Research, ISPA - Instituto Universitário, is funded by FCT (grant UID/PSI/04810/2019).

\section{ETHICS OF HUMAN SUBJECT PARTICIPATION.}

This study was conducted according to the guidelines laid down in the Declaration of Helsinki.

\section{REFERENCES}

American Psychological Association. (2003). Ethical principles of psychologists and code of conduct. Washington: APA.

Arcan, C., Neumark-Sztainer, D., Hannan, P., van den Berg, P., Story, M., \& Larson, N. (2007). Parental eating behaviours, home food environment and adolescent intakes of fruits, vegetables and dairy foods: longitudinal findings from Project EAT. Public Health Nutrition, 10(11), 12571265. doi: $10.1017 / \mathrm{s} 1368980007687151$ 
Bassuk, S. S., \& Manson, J. E. (2017). Obesity/overweight: health consequences. International Encyclopedia of Public Health, 277-294. doi:10.1016/b978-0-12-803678-5.00308-8

Baumrind, D. (1971). Current patterns of parental authority. Developmental Psychology, 4(2), 1103. doi:10.1037/h0030372

Baumrind, D. (1989). Rearing competent children. In W. Damon (Ed.), Child development today and tomorrow (pp. 349-378). San Francisco, CA: Jossey-Bass Publishers.

Behlin, O., \& Law, K. S. (2000). Translating questionnaires and other research instruments: problems and solutions. London, UK: Sage Publications.

Benton, D. (2004). Role of parents in the determination of the food preferences of children and the development of obesity. International Journal of Obesity, 28(7), 858-869. doi:10.1038/sj.ijo.0802532

Birch, L. L., \& Fisher, J. O. (2000). Mothers' child-feeding practices influence daughters' eating and weight. American Journal of Clinical Nutrition, 71(5), 1054-1061. doi:10.1093/ajcn/71.5.1054

Birch, L. L., Fisher, J. O., Grimm-Thomas, K., Markey, C. N., Sawyer, R., \& Johnson, S. L. (2001). Confirmatory factor analysis of the Child Feeding Questionnaire: a measure of parental attitudes, beliefs and practices about child feeding and obesity proneness. Appetite, 36(3), 201-210. doi:10.1006/appe.2001.0398

Byrne, B. M. (2016). Structural equation modeling with Amos: basic concepts, applications, and programming (3rd ed.). New York, NY: Routledge.

Carper, J. L., Fisher, J. O., \& Birch, L. L. (2000). Young girls' emerging dietary restraint and disinhibition are related to parental control in child feeding. Appetite, 35(2), 121-129. doi:10.1006/appe.2000.0343

Cohen, J. (1988). Statistical power analysis for the behavioral sciences (2nd ed.). Hillsdale, NJ: Lawrence Erlbaum Associates.

Cullen, K. W., Baranowski, T., Rittenberry, L., Cosart, C., Hebert, D., \& de Moor, C. (2001). Child-reported family and peer influences on fruit, juice and vegetable consumption: reliability and validity of measures. Health Education Research, 16(2), 187-200. doi:10.1093/her/16.2.187

Daniels, L. A., Magarey, A., Battistutta, D., Nicholson, J. M., Farrell, A., Davidson, G., \& Cleghorn, G. (2009). The NOURISH randomised control trial: positive feeding practices and food preferences in early childhood - a primary prevention program for childhood obesity. $B M C$ Public Health, 9(1), 387. doi:10.1186/1471-2458-9-387

Darling, N., \& Steinberg, L. (1993). Parenting style as context: an integrative model. Psychological Bulletin, 113(3), 487-496. doi:10.1037/0033-2909.113.3.487

Dickens, E., \& Ogden, J. (2014). The role of parental control and modelling in predicting a child's diet and relationship with food after they leave home. A prospective study. Appetite, 76, 23-29. doi:10.1016/j.appet.2014.01.013

Donin, A. S., Nightingale, C. M., Owen, C. G., Rudnicka, A. R., Cook, D. G., \& Whincup, P. H. (2017). Takeaway meal consumption and risk markers for coronary heart disease, type 2 diabetes and obesity in children aged 9-10 years: a cross-sectional study. Archives of Disease in Childhood, 103(5), 431-436. doi:10.1136/archdischild-2017-312981

Dubois, L., Girard, M., Potvin Kent, M., Farmer, A., \& Tatone-Tokuda, F. (2008). Breakfast skipping is associated with differences in meal patterns, macronutrient intakes and overweight among pre-school children. Public Health Nutrition, 12(1), 19-28. doi:10.1017/s1368980008001894 
Faienza, M. F., Wang, D. Q., Frühbeck, G., Garruti, G., \& Portincasa, P. (2016). The dangerous link between childhood and adulthood predictors of obesity and metabolic syndrome. Internal and Emergency Medicine, 11(2), 175-182. doi:10.1007/s11739-015-1382-6

Faith, M. S., Scanlon, K. S., Birch, L. L., Francis, L. A., \& Sherry, B. (2004). Parent-child feeding strategies and their relationships to child eating and weight status. Obesity Research, 12(11), 1711-1722. doi:10.1038/oby.2004.212

Fisher, J. O., Mitchell, D. C., Smiciklas-Wright, H., \& Birch, L. L. (2002). Parental influences on young girls' fruit and vegetable, micronutrient, and fat intakes. Journal of the American Dietetic Association, 102(1), 58-64. doi:10.1016/s0002-8223(02)90017-9

Galloway, A. T., Fiorito, L. M., Francis, L. A., \& Birch, L. L. (2006). 'Finish your soup': counterproductive effects of pressuring children to eat on intake and affect. Appetite, 46(3), 318323. doi:10.1016/j.appet.2006.01.019

Golan, M., \& Crow, S. (2004). Targeting parents exclusively in the treatment of childhood obesity: long-term results. Obesity Research, 12(2), 357-361. doi:10.1038/oby.2004.45

Gozal, D., Khalyfa, A., Qiao, Z., Smith, D. L., Philby, M. F., Koren, D., \& Kheirandish-Gozal, L. (2017). Angiopoietin-2 and soluble Tie-2 receptor plasma levels in children with obstructive sleep apnea and obesity. Obesity, 25(6), 1083-1090. doi:10.1002/oby.21859

Gregory, J. E., Paxton, S. J., \& Brozovic, A. M. (2011). Maternal feeding practices predict fruit and vegetable consumption in young children. Results of a 12-month longitudinal study. Appetite, 57(1), 167-172. doi:10.1016/j.appet.2011.04.012

Grolnick, W. S., \& Pomerantz, E. M. (2009). Issues and challenges in studying parental control: toward a new conceptualization. Child Development Perspectives, 3(3), 165-170. doi:10.1111/j.1750-8606.2009.00099.x

Hair, J. F., Black, W. C., Babin, B. J., \& Anderson, R. E. (2009). Multivariate data analysis (7th ed.). Upper Saddle River, NJ: Prentice Hall.

Hu, L., \& Bentler, P. M. (1995). Evaluating model fit. In R. H. Hoyle (Ed.), Structural equation modeling: concepts, issues, and applications (1st ed.). London: Sage Publications, Inc.

Hubbs-Tait, L., Kennedy, T. S., Page, M. C., Topham, G. L., \& Harrist, A. W. (2008). Parental feeding practices predict authoritative, authoritarian, and permissive parenting styles. Journal of the American Dietetic Association, 108(7), 1154-1161. doi:10.1016/j.jada.2008.04.008

Hughes, S. O., Power, T. G., Fisher, J. O., Mueller, S., \& Nicklas, T. A. (2005). Revisiting a neglected construct: parenting styles in a child-feeding context. Appetite, 44(1), 83-92. doi:10.1016/j.appet.2004.08.007

Hurley, K. M., Cross, M. B., \& Hughes, S. O. (2011). A systematic review of responsive feeding and child obesity in high-income countries. Journal of Nutrition, 141(3), 495-501. doi:10.3945/jn.110.130047

Jansen, E., Mulkens, S., \& Jansen, A. (2007). Do not eat the red food!: prohibition of snacks leads to their relatively higher consumption in children. Appetite, 49(3), 572-577. doi:10.1016/j.appet.2007.03.229

Jebb, S. A. (2005). Dietary strategies for the prevention of obesity. Proceedings of the Nutrition Society, 64(2), 217-227. doi:10.1079/PNS2005429

Kaufman, L., \& Karpati, A. (2007). Understanding the sociocultural roots of childhood obesity: food practices among Latino families of Bushwick, Brooklyn. Social Science \& Medicine, 64(11), 2177-2188. doi:10.1016/j.socscimed.2007.02.019

Kline, P. (2000). The handbook of psychological testing (2nd ed.). London: Routledge.

Kline, R. B. (2015). Principles and practice of structural equation modeling. (4th ed.). New York, NY: Guilford Press. 
Lock, K., Pomerleau, J., Causer, L., Altmann, D. R., \& McKee, M. (2005). The global burden of disease attributable to low consumption of fruit and vegetables: implications for the global strategy on diet. Bulletin of the World Health Organization, 83(2), 100-108. doi:/s004296862005000200010

Maccoby, E. E., \& Martin, J. A. (1983). Socialization in the context of the family: Parent-child interaction. In P. H. Mussen \& E. M. Hetherington (Eds.), Handbook of child psychology: Vol. 4. Socialization, personality, and social development (pp. 1-101). New York, NY: John Wiley \& Sons.

Marôco, J. (2014). Análise de equações estruturais: fundamentos teóricos, software e aplicações. Pêro Pinheiro, Portugal: Report Number.

Matton, A., Goossens, L., Braet, C., \& Van Durme, K. (2013). Continuity in primary school children's eating problems and the influence of parental feeding strategies. Journal of Youth and Adolescence, 42(1), 52-66. doi:10.1007/s10964-012-9794-3

Muc, M., Mota-Pinto, A., \& Padez, C. (2016). Association between obesity and asthma epidemiology, pathophysiology and clinical profile. Nutrition Research Reviews, 29(2), 194201. doi:10.1017/s0954422416000111

Musher-Eizenman, D., de Lauzon-Guillain, B., Holub, S. C., Leporc, E., \& Charles, M. A. (2009). Child and parent characteristics related to parental feeding practices. A cross-cultural examination in the US and France. Appetite, 52(1), 89-95. doi:10.1016/j.appet.2008.08.007

Neumark-Sztainer, D., Wall, M., Haines, J., Story, M., \& Eisenberg, M. E. (2007). Why does dieting predict weight gain in adolescents? Findings from project EAT-II: a 5-year longitudinal study. Journal of the American Dietetic Association, 107(3), 448-455. doi:10.1016/j.jada.2006.12.013

Northstone, K., \& Emmett, P. M. (2008). Are dietary patterns stable throughout early and midchildhood? A birth cohort study. British Journal of Nutrition, 100(5), 1069-1076. doi: $10.1017 / \mathrm{s} 0007114508968264$

Özçetin, M., Yilmaz, R., Erkorkmaz, U., \& Esmeray, H. (2010). Reliability and validity study of parental feeding style questionnaire. Turk Pediatri Arsivi, 45(2), 124-131. doi:10.4274/tpa.45.124

Palenzuela, D. L., Gerardo, P., Barros, A. M., \& Almeida, L. S. (1997). Una versión española de una batería de escalas de expectativas generalizadas de control (BEEGC). Revista Portuguesa de Educação, 10(1), 75-96.

Pan, X.-F., Tang, L., Lee, A. H., Binns, C., Yang, C.-X., Xu, Z.-P., . . . Sun, X. (2019). Association between fetal macrosomia and risk of obesity in children under 3 years in Western China: a cohort study. World Journal of Pediatrics. doi:10.1007/s12519-018-0218-7

Portuguese Psychologist Association. (2011). Código deontológico. Lisboa: OPP.

Rito, A. I., Sousa, R. C., Mendes, S., \& Graça, P. (2017). Childhood Obesity Surveillance Initiative - COSI Portugal 2016. Lisboa, Portugal: Ministério da Saúde. Instituto Nacional de Saúde Dr. Ricardo Jorge.

Rodenburg, G., Kremers, S. P., Oenema, A., \& van de Mheen, D. (2014). Associations of parental feeding styles with child snacking behaviour and weight in the context of general parenting. Public Health Nutrition, 17(5), 960-969. doi:10.1017/s1368980013000712

Schermelleh-Engel, K., Moosbrugger, H., \& Müller, H. (2003). Evaluating the fit of structural equation models: tests of significance and descriptive goodness-of-fit measures. Methods of Psychological Research, 8(2), 23-74. 
Silva, D. M. (2010). Expectativas generalizadas de controlo: tradução e adaptação da escala BEEGC-20., Centro de Estudos em Educação, Tecnologias e Saúde. Instituto Politécnico de Viseu.

Sleddens, E. F., Kremers, S. P., De Vries, N. K., \& Thijs, C. (2010). Relationship between parental feeding styles and eating behaviours of Dutch children aged 6-7. Appetite, 54(1), 30-36. doi:10.1016/j.appet.2009.09.002

Surkov, A., Pavlovskaya, E., Caroli, M., \& Kaganov, B. (2012). Validation of the Russian version of Parental Feeding Style Questionnaire and its applicability. Public Health Nutrition, 15(8A), 1590-1590. doi:10.1017/S1368980012002522

Tam, W., Keung, V., Lee, A., Lo, K., \& Cheung, C. (2014). Chinese translation and validation of a Parental Feeding Style Questionnaire for parents of Hong Kong preschoolers. BMC Public Health, 14(1), 1194-1200. doi:10.1186/1471-2458-14-1194

Unusan, N. (2006). How university students evaluate the grammatical style of nutrition messages? Nutrition Bulletin, 31(2), 100-103. doi:10.1111/j.1467-3010.2006.00557.x

Van Strien, T., Frijters, J., Bergers, G., \& Defares, P. (1986). Nederlandse Vragenlijst Voor Eetgedrag. Handleiding [Dutch Eating Behaviour Questionnaire. Manual]. Swets \& Zeitlinger B.V. Lisse.

Vartanian, L. R., Schwartz, M. B., \& Brownell, K. D. (2007). Effects of soft drink consumption on nutrition and health: a systematic review and meta-analysis. American Journal of Public Health, 97(4), 667-675. doi:10.2105/AJPH.2005.083782

Vaughn, A. E., Tabak, R. G., Bryant, M. J., \& Ward, D. S. (2013). Measuring parent food practices: a systematic review of existing measures and examination of instruments. International Journal of Behavioral Nutrition and Physical Activity, 10(1), 61-87. doi:10.1186/1479-5868-10-61

Ventura, A. K., \& Birch, L. L. (2008). Does parenting affect children's eating and weight status? International Journal of Behavioral Nutrition and Physical Activity, 5(1), 15-26. doi:10.1186/1479-5868-5-15

Vereecken, C., Legiest, E., De Bourdeaudhuij, I., \& Maes, L. (2009). Associations between general parenting styles and specific food-related parenting practices and children's food consumption. American Journal of Health Promotion, 23(4), 233-240. doi:10.4278/ajhp.07061355

Vereecken, C., Rovner, A., \& Maes, L. (2010). Associations of parenting styles, parental feeding practices and child characteristics with young children's fruit and vegetable consumption. Appetite, 55(3), 589-596. doi:10.1016/j.appet.2010.09.009

Viana, V., \& Sinde, S. (2003). Estilo alimentar: adaptação e validação do Questionário Holandês do Comportamento Alimentar. Psicologia: Teoria, Investigação e Prática, 8, 59-71.

Wardle, J., Sanderson, S., Guthrie, C. A., Rapoport, L., \& Plomin, R. (2002). Parental feeding style and the inter-generational transmission of obesity risk. Obesity Research, 10(6), 453-462. doi:10.1038/oby.2002.63

Wijnhoven, T. M., van Raaij, J. M., Yngve, A., Sjöberg, A., Kunešová, M., Duleva, V., .. . Breda, J. (2015). WHO European Childhood Obesity Surveillance Initiative: health-risk behaviours on nutrition and physical activity in 6-9-year-old schoolchildren. Public Health Nutrition, 18(17), 3108-3124. doi:10.1017/s1368980015001937

World Health Organization. (2014). New WHO analysis shows alarming rates of overweight children. Retrieved from http://www.euro.who.int/_data/assets/pdf_file/0013/243400/NewWHO-analysis-shows-alarming-rates-of-overweight-children.pdf 
Filipa Pimenta, Inês Queiroz Garcia, Sofia Cristina, Diana Galvão, João Marôco, \& Isabel

Leal

\section{APPENDIX}

\section{Parental Feeding Style Questionnaire (Versão Portuguesa)}

Por favor, leia as seguintes instruções e assinale com uma cruz a resposta que mostra a maneira como lida com a alimentação do seu filho. É importante ter em mente que não existem respostas certas ou erradas; estamos apenas interessados no que os pais sentem e fazem.

1. Permito que o(a) meu(minha) filho(a) escolha o que quer comer às refeições

2. Eu dou ao(à) meu(minha) filho(a) alguma coisa para comer, para o(a) fazer sentir-se melhor, quando se sente aborrecido(a)

3. Eu encorajo o(a) meu(minha) filho(a) a esperar com antecipado prazer pela refeição

4. Eu elogio o(a) meu(minha) filho(a) se ele(a) comer o que eu lhe der

5. Eu decido quantos lanches é que o(a) meu(minha) filho(filha) deve ter

6. Eu encorajo o(a) meu(minha) filho(a) a comer uma grande variedade de comida

7. De modo a conseguir que o(a) meu(minha) filho(a) se porte bem, eu prometo-lhe algo para comer

8. Eu apresento a comida de uma forma atrativa ao(à) meu(minha) filho(a)

9. Se o(a) meu(minha) filho(a) se portar mal, eu retenho a sua comida preferida

10. Eu encorajo o(a) meu(minha) filho(a) a provar cada uma das comidas que sirvo às horas de refeição

11. Eu permito que o(a) meu(minha) filho(a) ande de um lado para o outro durante uma refeição

12. Eu encorajo o(a) meu(minha) filho(a) a experimentar comida que nunca provou antes

13. Eu dou ao(à) meu(minha) filho(a) algo para comer para o(a) fazer sentir-se melhor, quando ele(a) se magoa

14. Eu deixo o(a) meu(minha) filho(a) decidir quando quer fazer a sua refeição

15. Eu dou ao(à) meu(minha) filho(a) alguma coisa para comer se ele(a) se sentir aborrecido(a)

16. Eu permito que o(a) meu(minha) filho(a) decida quando é que já comeu lanches suficientes

17. Eu decido quando é a hora de o(a) meu(minha) filho(a) lanchar

18. Eu uso sobremesas como um suborno para conseguir que o(a) meu(minha) filho(a) coma o seu prato principal

\begin{tabular}{|c|c|c|c|c|}
\hline 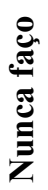 & 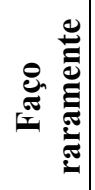 & 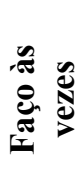 & 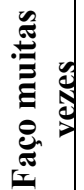 & 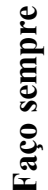 \\
\hline 1 & 2 & 3 & 4 & 5 \\
\hline 1 & 2 & 3 & 4 & 5 \\
\hline 1 & 2 & 3 & 4 & 5 \\
\hline 1 & 2 & 3 & 4 & 5 \\
\hline 1 & 2 & 3 & 4 & 5 \\
\hline 1 & 2 & 3 & 4 & 5 \\
\hline 1 & 2 & 3 & 4 & 5 \\
\hline 1 & 2 & 3 & 4 & 5 \\
\hline 1 & 2 & 3 & 4 & 5 \\
\hline 1 & 2 & 3 & 4 & 5 \\
\hline 1 & 2 & 3 & 4 & 5 \\
\hline 1 & 2 & 3 & 4 & 5 \\
\hline 1 & 2 & 3 & 4 & 5 \\
\hline 1 & 2 & 3 & 4 & 5 \\
\hline 1 & 2 & 3 & 4 & 5 \\
\hline 1 & 2 & 3 & 4 & 5 \\
\hline 1 & 2 & 3 & 4 & 5 \\
\hline 1 & 2 & 3 & 4 & 5 \\
\hline
\end{tabular}




\section{VALIDATION OF THE PFSQ PORTUGUESE VERSION}

\begin{tabular}{|c|c|c|c|c|c|c|}
\hline 19. & Eu encorajo o(a) meu(minha) filho(a) a apreciar a sua comida & 1 & 2 & 3 & 4 & 5 \\
\hline 20. & Eu decido as horas a que o(a) meu(minha) filho(a) faz as suas refeições & 1 & 2 & 3 & 4 & 5 \\
\hline 21. & $\begin{array}{l}\text { Eu dou ao(à) meu(minha) filho(a) algo para comer para o(a) fazer sentir-se } \\
\text { melhor, quando ele(a) está preocupado(a) }\end{array}$ & 1 & 2 & 3 & 4 & 5 \\
\hline 22. & $\begin{array}{l}\text { Eu recompenso o(a) meu(minha) filho(a) com algo para comer quando ele(a) se } \\
\text { porta bem }\end{array}$ & 1 & 2 & 3 & 4 & 5 \\
\hline 23. & Eu deixo o(a) meu(minha) filho(a) comer entre as refeições sempre que quer & 1 & 2 & 3 & 4 & 5 \\
\hline 24. & Eu insisto que o(a) meu(minha) filho(a) coma as refeições na mesa & 1 & 2 & 3 & 4 & 5 \\
\hline 25. & $\begin{array}{l}\text { Eu dou ao(à) meu(minha) filho(a) algo para comer para o(a) fazer sentir-se } \\
\text { melhor, quando ele(a) está zangado(a) }\end{array}$ & 1 & 2 & 3 & 4 & 5 \\
\hline 26. & Eu decido o que o(a) meu(minha) filho(a) come entre as refeições & 1 & 2 & 3 & 4 & 5 \\
\hline 27. & Eu elogio o(a) meu(minha) filho(a) se ele(a) comer uma comida nova & 1 & 2 & 3 & 4 & 5 \\
\hline
\end{tabular}

